\title{
Understanding copper homeostasis in humans and copper effects on health
}

\author{
MAGDALENA ARAYA, FERNANDO PIZARRO, MANUEL OLIVARES, \\ MIGUEL ARREDONDO, MAURICIO GONZÁLEZ and MARCO MÉNDEZ
}

Institute of Nutrition and Food Technology (INTA), Universidad de Chile

Concern about human exposure to copper derives from the fact that virtually all individuals are exposed to it in one way or another, yet the knowledge about the effects of chronic excess copper on human health is clearly insufficient. $\mathrm{Cu}$ is an essential micronutrient that participates in several processes crucial for life, but at the same time, it may be toxic to cell membranes, DNA and proteins when accumulated in excess $(1,6,10)$. In man, mechanisms regulate uptake, efflux, storage and utilization of $\mathrm{Cu}$ preventing adverse effects due to excess within a rather wide range of (dietary) exposure. $\mathrm{Cu}$ handling appears tightly regulated, but the upper and lower limits of its homeostatic regulation are unclear. When exposure is high enough to induce clinically apparent manifestations, the available markers are efficient and helpful for diagnosis. However, these markers are not sensitive enough to reveal less intense changes of $\mathrm{Cu}$ status, which may be relevant in long-term human health $(2,7)$. Here, we review a series of studies in humans that we have performed to explore the capacity to handle copper loads and the limits of copper homeostasis in humans.

In a first, preliminary study, apparently healthy women (20-45y) who had an estimated daily intake of $0.9 \mathrm{mg}$ of copper per day $(9,11)$ were exposed to a three- to fourfold increase in their basal estimated copper exposure. Although acute gastrointestinal symptom report increased, no changes were detected in the distribution curves of serum copper and ceruloplasmin
Cp (3). In a second study, healthy adults were exposed to an extra 15 to $150 \mu \mathrm{g} / \mathrm{kg} / \mathrm{d}$, provided via water consumed at home, which was ingested mixed with fluids and food during the day $(2,3)$. Although in a proportion of the participants the long-term copper consumption prior to the study was estimated borderline low ( $0.9 \mathrm{mg} \mathrm{Cu} /$ day $)$, there was no significant increase in erythrocyte superoxide dismutase (eSOD) activity after the two-month exposure period. This result did not support the measurement of eSOD as a potential indicator of marginal copper deficiency. Expressed as mean values $\pm \mathrm{SD}$, copper concentrations (in serum, red blood cells and mononuclear cells), serum/plasma $\mathrm{Cp}$, and eSOD activity were within the normal range and were not related to copper intake (ANOVA, NS). The non-Cp copper fraction was positively correlated to serum copper ( $\mathrm{r}$ $=0.58)$. Activity of liver aminotransferases, measured as indicators of liver function, remained within normal limits.

In the next study, we assessed the effect of the Upper Level (UL) of dietary recommendations in apparently healthy adults $(4,5,8)$. The UL value is a concept developed for regulatory purposes to define safe limits of intake for the normal human. It is the level of intake from food, water and supplements that is unlikely to pose risks of adverse health effects from excess over the long term, in apparently healthy individuals, in an age- and sex-specific population group (5). Although $\mathrm{Cp}$ is not a good indicator when infectious or inflammatory processes 
are present, it is one of the indicators used clinically to detect alterations of copper metabolism - for example, in patients suspected to suffer Wilson's disease (12). We decided to explore the capacity of this protein to show differential responses to copper intake among normal individuals. We hypothesized that healthy individuals would respond to $\mathrm{Cu}$ in accordance with their place in the serum $\mathrm{Cp}$ distribution curve, considering a lower value as an index of long-term lower intake (4). Thus, two study groups were formed considering the individual serum $\mathrm{Cp}$ values (low $\mathrm{Cp}$ and high $\mathrm{Cp}, \mathrm{n}=41$ per group). The study was a prospective controlled trial; participants (women and men, 18-50 years) belonged to the upper and lower decile of the $\mathrm{Cp}$ distribution curve obtained in 800 healthy adults. Participants ingested a single daily dose of $10 \mathrm{mg} \mathrm{Cu} / \mathrm{d}$ for 60 days. Before and immediately after the $\mathrm{Cu}$ supplementation period, blood (serum $\mathrm{Cu}, \mathrm{Cp}$ protein, homocysteine, liver GOT, GPT and GGT, $\mathrm{Zn}-\mathrm{Cu}-\mathrm{SOD}$ activity in erythrocytes, glutathione and IL-2 production and SOD and CCS mRNA expression in peripheral mononuclear cells, and HCTR1 and DMT1 mRNA expression in monocytes) and urine (urinary $\mathrm{Cu}$ excretion after DMPS Dimaval $^{\mathrm{R}}$ - challenge) studies were performed.

After one month, liver enzyme activities remained unchanged, but after two months, liver enzymes significantly increased in both groups and sexes, although they remained below the cut-off used to diagnose clinical liver dysfunction. These differences disappeared 12 months after the $\mathrm{Cu}$ supplementation was discontinued. Glutathione in peripheral mononuclear cells also increased in both $\mathrm{Cp}$ groups and in both genders (each $p=0.01$ ). HCTR 1 but not DMT1 mRNA expression in monocytes significantly increased after the two-month load. Our interpretations of these results were as follows: 1) in apparently healthy individuals, $\mathrm{Cu}$ administered in the regimen described induces transient elevation of aminotransferases and a possibly compensatory rise in mononuclear blood cell glutathione, suggesting that this load increases oxidative stress, reaches a limit in homeostasis and the associated changes are reversible; and 2) HCTR 1 mRNA expression in monocytes might be a marker of early changes in copper status and deserve further investigation.

In an additional analysis aimed at identifying factors that may modulate the response to copper exposure, Principal Component Analysis and Linear Discriminant Analysis were used to assess blood and urinary $\mathrm{Cu}$ indicators that showed a differential response to $\mathrm{Cu}$, as a function of sex (8). This analysis revealed that individual $\mathrm{Cp}$ values in serum reliably differentiate subgroups within the normal population in their response to excess $\mathrm{Cu}$. The responses detected were dependant both on the $\mathrm{Cp}$ values and on sex: women with higher and men with lower $\mathrm{Cp}$ values exhibited the greatest response to excess $\mathrm{Cu}$.

In a subsequent study, we further explored the effect of chronic excess copper exposure in apparently healthy adult men who received $8 \mathrm{mg} \mathrm{Cu} /$ day for 6 months. Preliminary results showed no detectable changes in liver enzymatic activities nor in indicators of oxidative stress, indicating that administration of $8 \mathrm{mg} \mathrm{Cu}$ /day for 6 months is handled adequately by homeostatic mechanisms. ANOVA analysis for repeated measures confirmed that the variable copper (dosing) was not related significantly to the indicators measured; however, there was a significant association between the variable time and the indicators measured, suggesting that seasonality is a factor that influences the responses to copper exposure.

To learn about the impact of an acute dose of copper on the indictors that evaluate copper status, liver function and oxidative stress were explored during the same 6month protocol. A single, $10 \mathrm{mg} \mathrm{Cu}$ (as copper sulfate) or placebo dose was administered to a subgroup of participants immediately before and after finishing the protocol. After $12 \mathrm{hrs}, 1,3$ and 7 days of dosing, blood samples were drawn and indicators were measured. Preliminary results show that curves of serum LDH activity in the experimental individuals were no different in comparison to those of the placebo subjects during the 7-day evaluation. 
In contrast, serum copper curves were significantly different in the experimental and placebo groups both prior to and after copper supplementation (Fig. 1). That individuals receiving the copper supplement did not have as large an increase after the second acute copper dose (i.e. after 6 months of receiving $8 \mathrm{mg} \mathrm{CuSO} /$ d) suggests an adaptation to remove copper from the blood more rapidly. It is interesting that changes of serum zinc curves during the study were not related to copper administration, but to variable "time" (Fig. 2), showing an increase after 12 hrs of dosing, both in the experimental and placebo groups, suggesting a circadian rhythm rather than a response to copper dosing.

In summary, these studies shed light on the effects of chronic and acute copper

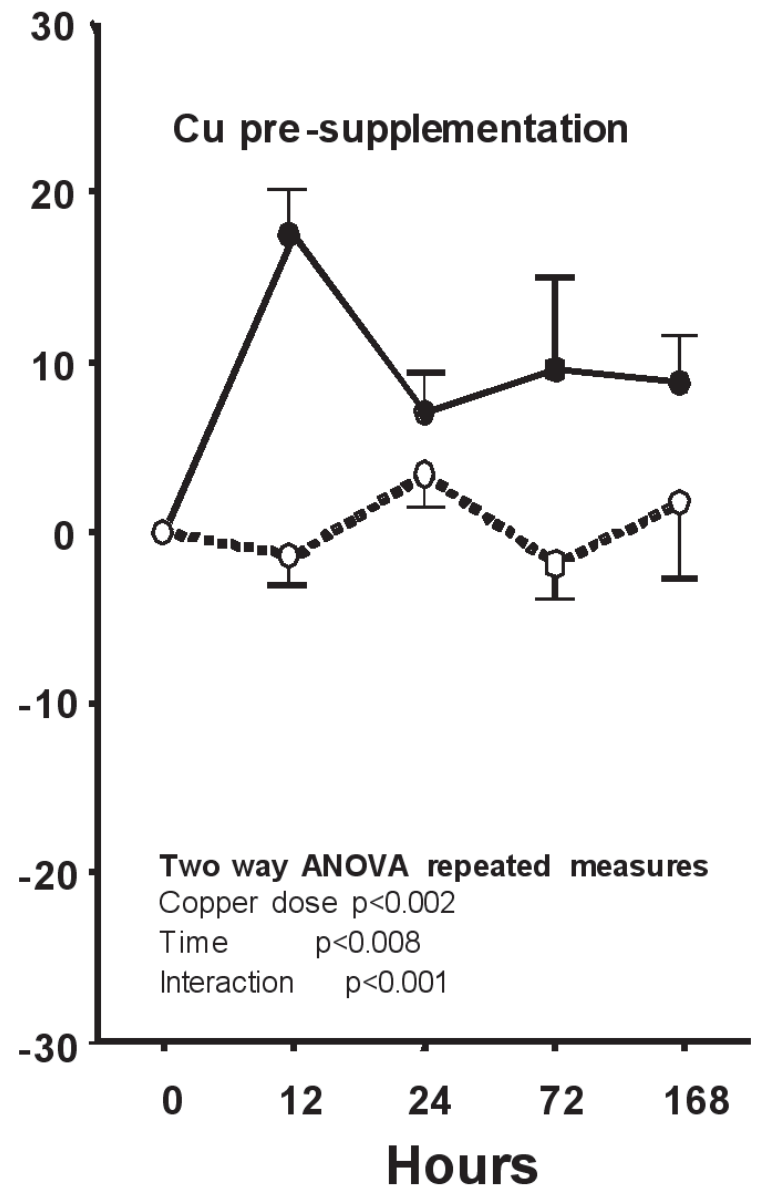

dosing in healthy adults. In the chronic studies, the administration of $10 \mathrm{mg} \mathrm{Cu} / \mathrm{d}$ mixed with food for two months did not induce adaptive responses, but $10 \mathrm{mg} \mathrm{Cu} / \mathrm{d}$ administered as a single dose per day (mimicking a daily bolus) during two months provoked a transient response of liver enzyme activities and of peripheral mononuclear cell glutathione. A dose of 8 mg Cu per day for 6 months did not trigger detectable responses but showed that seasonality is likely to be another variable that influences the responses observed. Considering that $10 \mathrm{mg}$ of copper per day represents an Upper Limit for human chronic consumption of copper, further studies should clarify the safety of this figure when different regimens are used. In the acute studies, the differences observed

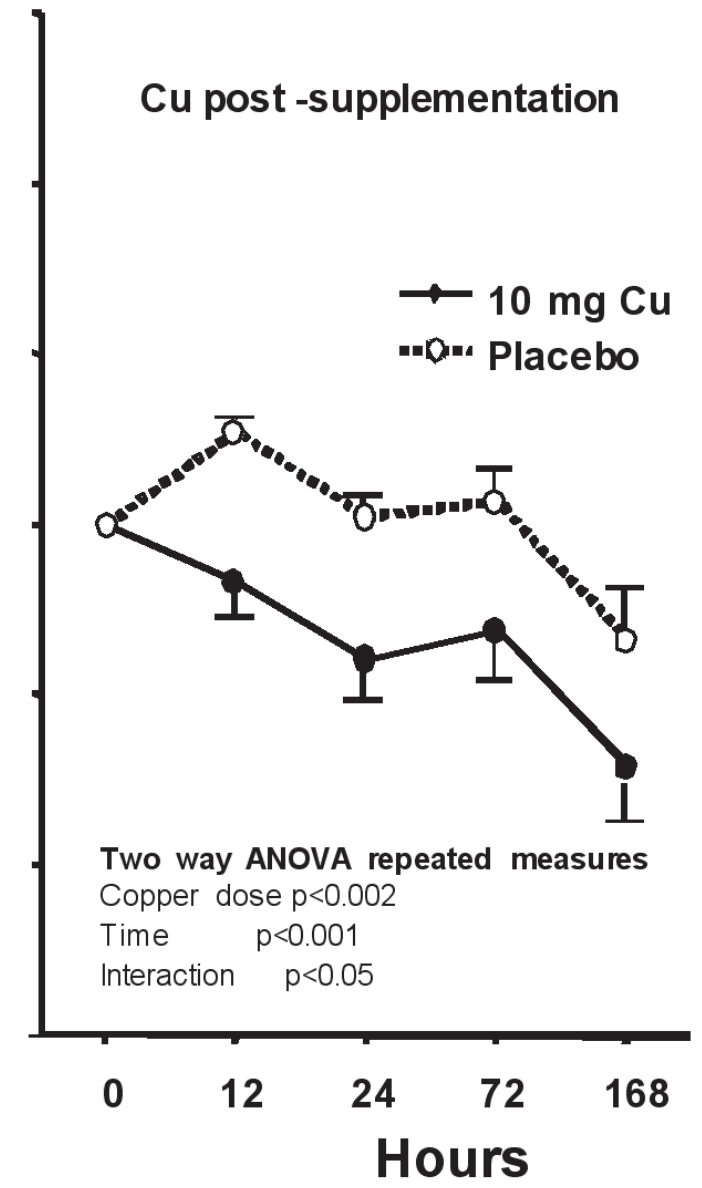

Figure 1. Acute handling of copper before and after copper load. Serum copper in the experimental and placebo groups, after 12, 24, 72 and $168 \mathrm{hrs}$ of a single $10 \mathrm{mg}$ copper dose copper (as copper sulfate), prior to and after supplementation with $8 \mathrm{mg} \mathrm{Cu} /$ day for 6 months. 


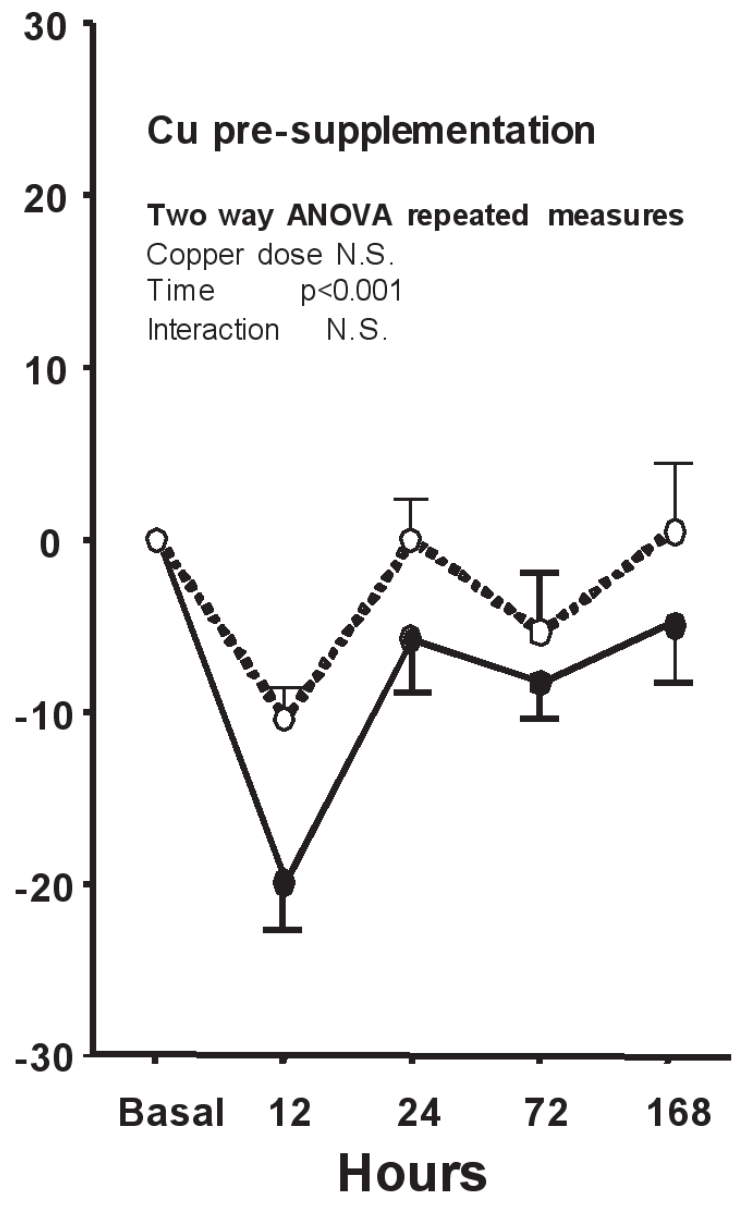

\section{Cu post -supplementation}

Two way ANOVA repeated measures Copper dose N.S.

Time $\quad p<0.02$

Interaction N.S.
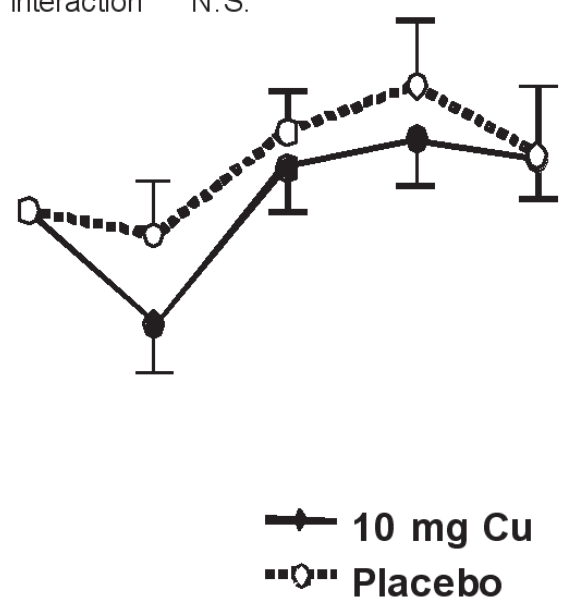

Placebo

Figure 2. Acute handling of zinc before and after copper load. Serum zinc in the experimental and placebo groups, after 12, 24, 72 and $168 \mathrm{hrs}$ of a single $10 \mathrm{mg}$ copper dose copper (as copper sulfate), prior to and after supplementation with $8 \mathrm{mg} \mathrm{Cu}$ /day for 6 months.

in serum copper curves after a single dosing of $10 \mathrm{mg}$ copper (as copper sulfate) suggest that adaptation to copper takes place after 6 months of loading; however, the results do not permit speculation about the mechanisms involved. In addition, these studies show that individuals' Cp concentration in serum reliably differentiate subgroups within the normal population in their response to excess $\mathrm{Cu}$.

\section{REFERENCES}

1. ARAYA M, GONZÁLEZ M, OLIVARES M, UAUY U (2002) Biological effects of chronic copper exposure. In: MASSARO E (ed) Copper Pharmacology and Toxicology. Totowa, New Jersey: Humana
2. ARAYA M, OLIVARES M, PIZARRO F, GONZÁLEZ M, SPEISKY H, UAUY R (2003) Gastrointestinal symptoms and blood indicators of copper load in apparently healthy adults undergoing controlled copper exposure. Am. J. Clin. Nutr. 77: 646-650

3. ARAYA M, OLIVARES M, PIZARRO F, LLANOS A, FIGUEROA G, UAUY R (2004) Community-based randomized double-blind study of gastrointestinal effects and copper exposure in drinking water. Environ. Health. Perspect. 112: 1068-1073

4. ARAYA M, OLIVARES M, PIZARRO F, MÉNDEZ M, GONZÁLEZ G, UAUY R. (2005) Effects of a copper supplement at the upper level (UL) of recommendations in adults. $\mathrm{J}$ Nutrition, in press

5. INSTITUTE OF MEDICINE, FOOD AND NUTRITION BOARD (2001) Dietary reference intakes for vitamin A, vitamin $\mathrm{K}$, arsenic, boron, chromium, copper, iodine, iron, manganese, molybdenum, nickel, silicon, vanadium, and zinc. Washington, D.C.: National Academy Press

6. IPCS Environmental Health Criteria (1998) Copper. Geneva: World Health Organization, No. 200 
7. KEHOE CA, TURLEY E, BONHAM MP, OCONNOR M, MCKEOWN A, FAUGHAN MS, COULTER JS, GILMORE WS, HOWARD AN, STRAIN JJ (2000) Response of putative indices of copper status to copper supplementation in human subjects. Br. J. Nutr. 84: 151-156

8. MÉNDEZ MA, ARAYA M, OLIVARES M, PIZARRO F, GONZÁLEZ M (2004) Sex and Cp modulate the response to copper exposure in healthy individuals. Environ Health Perspect 112(17): 1654-1657

9. OLIVARES M, PIZARRO F, DEPABLO S, ARAYA M, UAUY R (2004) Iron, zinc and copper: Contents in common Chilean foods and daily intakes in Santiago City, Chile. Nutrition 20: 205-212
10. OLIVARES M, UAUY R (1996) Copper as an essential element. Am J Clin Nutr 63: 791S-796S

11. PIZARRO F, OLIVARES M, UAUY R, CONTRERAS P, REBELO A, GIDI V (1999) Acute gastrointestinal effects of graded levels of copper in drinking water. Environ Health Perspect 107: 117-121

12. PLESKOW RG, GRANT RJ (1991). Wilson's disease. In: WALKER WA, DURIE PR, HAMILTON JR, WALKER-SMITH JA, WATKINS JB (eds) Pediatric Gastroenterology Disease. Toronto: BC Decker. pp: 1014-1025 